\title{
Extent of School-Based Management Committee Involvement in Public Secondary Schools Administration in Abuja, Nigeria
}

\author{
Orji Friday Oko $^{1^{*}(\mathbb{C}}$, Mando Patricia Nguwasen ${ }^{2}$, Nzewi Felicia Ebelechukwu ${ }^{1}$ \\ ${ }^{1}$ Department of Educational Management and Policy, Nnamdi Azikiwe University, Awka, Nigeria \\ ${ }^{2}$ Department of Educational Foundations and General Studies, Federal University of Agriculture, Makurdi, Nigeria \\ E-mail: orjifridayoko@gmail.com
}

Received: 13 August 2021; Revised: 16 October 2021; Accepted: 26 October 2021

\begin{abstract}
Given that managing schools to attain expected goals is becoming challenging in the present competitive society, it becomes paramount that collaborations, especially with a highly innovative group of people are encouraged. In the light of this, the purpose of this study is to investigate the extent of School-Based Management Committees' (SBMCs) involvement in public secondary school administration in Abuja. A descriptive survey design was used for the study, and 3 research questions were answered in relation to the 3 research objectives of the study. The population of the study was 460 respondents, and a sample size of 250 respondents was drawn through proportionate random and convenience sampling techniques. A structured questionnaire was used for data collection. Arithmetic mean was employed in analyzing the research questions. The result revealed among others, that the school-based management committees play a passive role in planning in public secondary schools in Abuja. It was concluded that for schools to effectively meet the academic need of the Abuja community, their collaborations with the SBMCs have to be very active and productive. To this end, SBMCs need to become more committed to collaborating and helping the schools in terms of planning, staffing and monitoring.
\end{abstract}

Keywords: School-Based Management Committees (SBMCs), school administration, school administrator, planning, staffing, monitoring

\section{Introduction}

The School-Based Management (SBM) framework in Nigeria dates all the back to the colonial times when School Management Committees (SMCs) oversaw and raised asserts for schools (Caldwell, 2005). During this time, responsibilities of SMCs, like raising assert and ensuring effective appropriation and utilisation of the assets were considered priceless. The global reform of education of the 1990s and 2000s influenced the Nigerian Government to institutionalise the SBM system because it was obvious that funding and managing education is better decentralized for improved synergy and collaborations. Caldwell (2005) stressed that School-Base Management system was strengthened in 2005 when the National Council on Education (NCE) at its 52nd Meeting directed that all schools should establish School-Based Management Committees (SBMCs) to ensure that local communities participate in the schools' decisionmaking process. In consolidation to the establishment of SBMCs in schools, Ahmed and Kazi (2013) added that the Federal Ministry of Education (2006), through the Universal Basic Education Commission (UBEC), thereafter issued

Copyright (C2021 Orji Friday Oko, et al.

DOI: https://doi.org/10.37256/ser.3120221096

This is an open-access article distributed under a CC BY license

(Creative Commons Attribution 4.0 International License)

https://creativecommons.org/licenses/by/4.0/ 
guidelines to all State Universal Basic Education Boards (SUBEBs) and Local Government Education Authorities (LGEAs) on the best way to build up SBMCs in their schools.

In a bid to ensure effective participation of local communities in the management of affairs of schools, the National Council on Education (NCE) in 2006 supported the implementation of SBMCs in all primary and secondary schools in Nigeria, as a feature of government strategy to restructure the school administrative process and ensure inclusive participation of stakeholders in the school management at the community level. In 2007, the government made the implementation of SBMCs mandatory and suggested that the SBMC be made up of 12 to 19 people in each school (Ayeni, 2012). This was expected to be achieved through the involvement of meaningful, close, strong and goal-oriented partnership between the school authority and other relevant stakeholders (Parent-Teachers Association (PTA), Old Students Association, Communities, Traditional Institution, Civil Society Organizations, Faith-Based Organizations, Ministries, and other professional and social institutions). This synergy, according to Eziuzo and Enueme (2013), is fundamental in light of the fact a virile and responsive school-community relationship is a building block for sustainable quality education.

School-based administration is a favourable intervention strategy for enhancing the nature of institutional administration, asset inputs, educational plan execution, and students' scholarly accomplishment in schools (Ananda, 2007). It involves the cycle of devolution of force and position to important partners in the SBMCs. This is to engage them to perform fitting legal obligations that could work on the situation in the schools. These obligations incorporate, yet are not restricted to the organisation, monitoring, assessment and audit of schooling approaches for economically viable instructing and learning. SBMC is an objectively arranged administrative structure set up to improve teaching and learning, in order to accomplish set objectives at different schools. SBMCs are prominent and strategic in coping with the task of improving the quality of educational practices in countries that have advocated for it. SBMCs are basically set up to decentralise the decision-making process in educational policy issues, so as to encourage democratic principles, community participation, equity, and integration of diverse local interests and needs in schools' management. Might (2015) stressed that the decentralization policy on school management is premised on the fact that local communities are closer to the schools and understand their problems and needs better. Consequently, they are more effective and proactive in handling issues in schools.

School-based management is a formal alteration of governance structures, a form of decentralization that identifies the individual school as the primary unit of improvement and relies on the redistribution of decision-making authority as the primary means through which improvement are stimulated and sustained (Caldwell, 2005). This means that in SBMCs, the responsibility for decision-making authority over school operations is transferred from the government (owners of schools) to principals, teachers, old students, parents, and other select community members. In general, School-Based Management Committee programs transfer authority over one or more of the following activities: budget allocation, the hiring and firing of teachers and other school staff, curriculum development, the procurement of textbooks and other educational material, infrastructure improvements, and the monitoring and evaluation of teacher performance and student learning outcomes (Agustinus, 2009). For the purpose of this study, SBMCs' functions are limited to planning, staffing and monitoring of activities of schools in Abuja.

School administration is a vital determinant for the realization of desired outcomes and successes in both public and non-public schools, consequently, it is viewed as fundamental by partners (Orji \& Umoren, 2016). According to Orji et al. (2016), 'administration is a social process concerned with identifying, maintaining, motivating, controlling and unifying formally and informally organized human and material resources within an integrate system designed specifically to achieve predetermined objectives. Administration simply entails planning, organising and controlling the various aspect of the firm with a common purpose of achieving set goals. School administration, therefore, entails the activities of planning, organizing, coordinating, controlling, commanding, directing, evaluating, staffing and motivating teachers, non-teaching staff members, students and others towards the attainment of the overall goals of the school system. These administrative elements are put into practice by the administrator(s) within the school setting for actualizing set educational goals. Nwaka et al. (2012) explained that school administrators are the administrative heads in the schools' systems that are entrusted with the management of both human and material resources in the schools for effective implementation of educational policies and programmes.

Planning is a strategic way of looking into the future necessities, through today's inner eyes and thought processes and fine-tuning what, when, where, who and how best to attain the needs (Orji, 2016). He further explained that 
planning has to do with envisioning and foreseeing the gap between today's and tomorrow's needs, and making adequate and strategic preparations today, on how to fill the gap. In the school system, SBMCs are expected to be involved in planning and taking decisions relating to curriculum implementation, recruitment, infrastructure development and maintenance, financial mobilization and allocations, among others. However, it is not ascertained whether or not SBMCs have actually been carrying out these responsibilities, especially among public secondary schools in Abuja.

Staffing involves all endeavors of schools at identifying the sorts of workforce required, just as enrolment and improvement programs aimed at making human assert active and relevant for defined tasks. It goes to the extent of considering the potential employee's ability, trainability, commitment and ways to ensure he is happy and satisfied to continue contributing positively to the school pursuit of excellence. SBMCs are expected to participate in performing this role in terms of recruitment, training, promoting, rewards and evaluating the teaching and non-teaching members of staff of the schools in Abuja.

Monitoring is likened to checkmating and keeping an eye on ongoing activities to ensure that implementations are being done according to approved specifications and standards. School is an organized and formal establishment through which the curriculum of the nation is implemented and evaluated. SBMCs also have to be involved in other activities, such as extra-curricular, physical structural development and maintenance, human resource management, students' affair and welfare, community and school relationships, among others, which need to be monitored to ensure adequate and successful translation of what exist on paper into observable realities (Cranston, 2001). This is part of the tasks the SBMCs are assigned to perform in schools.

However, Hon and Alison (2014) lamented that state-funded schools in Abuja only complied with the directives of the National Council on Education (NCE) in 2006 by setting up SBMCs, but a few years later, SBMCs have become merely ceremonial and dysfunctional. The researchers observed that there have been lapses in the schools with regard to planning, staffing, and monitoring. It was observed that some of the schools in Abuja do not have enough human and material resources to implement school programmes. More so, some of the schools' staff do not comply with their schools' code of conduct; yet, such attitude is not checked and corrected. In addition, some of the schools' plans for the next five to ten years do not seem to have been properly documented. These issues cast doubt on whether or not, SBMCs in public secondary schools in Abuja have actually been carrying out their partnership responsibilities for the schools, in the area of planning, staffing and monitoring. In the light of these issues, the purpose of this study was to investigate the extent of school-based management committees' involvement in public secondary schools administration in Abuja.

\section{Literature review}

\subsection{Roles and responsibilities of School-Based Management Committees}

SBMCs have numerous roles they are expected to play to ensure the schools move forward, and continue to attain their educational goals. It is almost impossible to exhaust the functions of SBMCs in an article of this nature. However, Garry cited in Ahmed and Kazi (2013), highlighted the functions of SBMCs in Nigeria to include:

"effective participation in the overall learning outcomes of pupils and students; effective participation in school development planning process; networking with other stakeholders, promoting partnerships and inclusion of women and children towards improved quality and inclusive education through proactive monitoring of school activities; resource mobilization for school improvement; community sensitization towards ensuring improved enrolment of pupils/students, retention, completion and transition; providing support and motivation for teachers and learners; collaboration with local communities to provide safety for teachers, learners and school property; oversight functions on funds allocation and utilisation for school improvement, as well as collaborating with the schools for improvement of staff base of the school" (p. 92).

The above provided a summary of the fundamental responsibilities of the SBMCs. Aside from other functions, it pointed out that SBMCs are statutorily expected to collaborate with the schools in the areas of monitoring, staffing, and planning practices to improve schools' effectiveness.

In relation to SBMC's collaboration with schools in the planning process, Ayeni (2010) asserted that School-Based Management Committees get involved in short and long-term planning of their schools based on the communities' expectations, and government educational priorities; set goals and targets for their schools; define strategies for 
achieving the goals towards improving the learning outcomes of learners; planning for staff activities, as well as budget planning for priority projects. The implication of the foregoing is that SBMCs are fundamentally instituted to be collaborating with the schools in planning for possible repairs and maintenance needs in schools; provision of potable water; support to vulnerable schooling children; sports development; provision of self-sponsored physical facilities; enhancement of security operatives; support in the provision of learning materials, and first-aid items, among others.

The role of SBMCs in ensuring the availability and functionality of school staff cannot be over-emphasized. Saeid et al. (2012) pointed out that the welfare and security of the school's staff is a priority need which the SBMCs are expected to aid in. Supporting this, Orji et al. (2016) added that the committees are needed to aid in staff support mechanisms, maintenance of staff discipline, staff capacity development and incentives, maintenance of good and peaceful working conditions for staff, as well as the orientation of staff members, especially the new ones, in order to improve the school-community relationship.

The monitoring role of SBMCs is based on the fact that the community has the legitimate mandate in education. This mandate authorizes SBMCs to periodically get involved in monitoring, reviewing, evaluating and giving constructive advice to schools on key issues in curriculum delivery, critical infrastructure, capacity building, and instructional materials/equipment (Ayeni, 2012). By the legitimate status of the SBMCs in schools, they are regarded as the key instruments for ensuring that school/community decisions and priorities are translated into tangible school improvements. The SBMCs perform oversight functions in the implementation and monitoring of the utilisation of funds provided for school improvement, instructional activities, and school resources as well as reporting back to the larger community on their observations.

\subsection{Theoretical model}

The school-based management (SBM) model was developed by E. Hanushe and L. Woessmann L. in 2007. The tenets of the SBM model were centered on choice and competition, autonomy, and accountability. In terms of choice and competition, the model argued that parents have the right to choose the SBMC to be part of, whether their kids are enrolled there or not. The choice they make might be influenced by the willingness of the schools to keep pursuing academic excellence. In this situation, parents might want to align with the potential success stories of such schools. In relation to autonomy, the SBM model argued that a school should be in a position to collaborate with SBMC members in planning for, and getting involved in fund generation, material supports, and employment of supportive staff or ad hoc staff for the school, and ensuring that the staff welfare and maintenance of school facilities are prioritized without undue interferences. On the part of accountability, the SBM model asserted that SBMCs are expected to help in improving students' achievement and staff compliance to school programmes. They have to actively collaborate with the schools in monitoring and supervising school personnel in instructional delivery, facility maintenance and rehabilitation, and general administration. The SBM model is related to this study, as the model's tenets provided the fundamental explanations of the roles that SBMCs are required to play by collaborating with the schools in the areas of planning, staffing, and monitoring.

\subsection{School-Based Management Committees model}

In terms of the SBMC model, Hanushek and Woessmann (2007) examined four policy options for making decisions in terms of the structure in which power is to be vested for the effective operations of the SBMCs. This SBM model was examined under four reforms or policies and could be applied anywhere across the globe. The four perspectives to determine which structure is to be entrusted with control power include administrative control; professional control; community control, and balanced control. These are briefly examined hereunder:

- Administrative Control: This suggests that SBM devolves authority to the school principal. This model aims to make each school more accountable to the central district or board office. The benefits of this kind of SBM include increasing the efficiency of expenditures on staff, curriculum implementation, and program monitoring. This helps in making the principal at each school more accountable to the central authority.

- Professional Control: SBM model based on this perspective devolves the main decision-making authority to teachers. This model aims to make better use of teachers' knowledge of what the schools need at the classroom level. In this case, guaranteeing teachers' full participation in the decision-making process of the SBMC could motivate teachers 
to be more committed in the discharge of their responsibilities to the school. This perspective supposes that greater efficiency and effectiveness could be attained in teaching.

- Community Control: This SBM ideology argues that the main decision-making authority is given to parents and the community in general. Under this model, teachers and principals are assumed to become more responsive to parents' needs. The school is expected to embrace the curriculum and implement a curriculum that takes cognizance of local needs and preferences.

- Balanced Control: The balanced SBM perspective encouraged decision-making authority to be fairly shared between the parents and teachers, which are the two main stakeholders in any school. The aim is to take advantage of teachers' detailed knowledge of the school to improve school management, and to make schools more accountable to parents and the community.

However, it is understandable from the above that there is no model that is most appropriate and encompassing, rather the various models are better combined to ensure that the benefits from each model are well exploited.

\section{Research gap}

The study was necessitated by a lack of research and literature particularly in Abuja with regard to activities and functionality of SBMCs in the schools they were instituted to collaborate with. To provide an empirically based literature on how proactive SBMCs have been in collaborating with public secondary schools in Abuja in terms of planning, staffing and monitoring, this study was given birth to.

\section{Purpose of the study}

The major purpose of the study was to examine the extent of school-based management committees' involvement in public secondary schools administration in Abuja, Nigeria. Specifically, the study investigated the extent to which:

1. SBMC has been getting involved in planning in public secondary schools in Abuja.

2. SBMC is greatly participating in staffing in public secondary schools in Abuja.

3. SBMC has been collaborating with public secondary schools in monitoring activities in Abuja.

\section{Research questions}

The following research questions guided the study:

1. How has SBMC been getting involved in planning in public secondary schools in Abuja?

2. In what ways has SBMC been participating in staffing public secondary schools in Abuja?

3. To what extent has SBMC been collaborating with public secondary schools in monitoring activities in Abuja?

\section{Methodology}

The study adopted the descriptive survey research design. Descriptive survey research design is often used when a researcher intends to elicit responses from a relatively large number of respondents by administering pertinent instruments for collecting primary data on a portion of the population known as sample (Orji et al., 2016). The design was considered appropriate for the study, since it will guide the researcher in collecting, collating and analysing data from representative or samples of principals, in order to describe, compare and make a generalisation on their observations as regard SBMCs' involvement in school administration in Abuja. The population of the study was 460 respondents, which comprised all the 92 principals in public secondary schools, and the 368 members of SBMCs in Abuja, Nigeria. The choice of school principals was based on the fact that they are important members of SBMC in their various schools. The sample size of 250 respondents was drawn through proportionate random sampling technique and convenience sampling technique. The proportionate sampling technique was employed in drawing 50 principals 
of public secondary schools in Abuja, and this represents approximately $54 \%$ of the principals. This was based on St. Otaf College's (2021) recommendation that a minimum of 30\% is drawn for a population below 1,000 to ensure representativeness. Hence, the researchers decided to draw $54 \%$ of the principals. Finally, a convenience sampling technique was adopted in selecting 200 members of SBMCs to respond to the structured questionnaire across the 50 selected public secondary schools in Abuja. In each school, 4 SBMC members, based on willingness and availability, responded to the research instrument. Convenience sampling was applied based on the fact that it ensures speedy, easy, and reduced cost of collecting from arrays of readily available and willing respondents.

The researchers developed a well-structured instrument, titled a Questionnaire on the Extent of School-Based Management Committee Involvement in Secondary Schools Administration in Abuja (QTESBMCISSAA) for data collection. The questionnaire has two sections, namely: section A which contains the demographic data of the respondent, and section B which contains 15 questionnaire items that were coined out of the 3 research objectives and 3 research questions in relation to SBMCs involvement in planning, staffing and monitoring in public secondary schools in Abuja. The response patterns for the questionnaire four-point rating scale, in which Very High Extent (VHE) was assigned 4 points; High Extent (HE) was assigned 3 points; Low Extent (LE) was assigned 2 points, and Very Low Extent (VLE) was assigned 1 point.

Copies of the questionnaire were examined and approved for face and content validity by 2 research experts and lecturers in the department of educational management, University of Abuja. Cronbach Alpha was adapted to ascertain the reliability of the instrument. The results of the Cronbach Alpha tests are 0.699 for SBMCs involvement in school's planning; 0.781 for SBMCs involvement in school's staffing; 0.791 for SBMCs involvement in monitoring activities in the school. However, the average of the above coefficients of Cronbach Alpha is 0.757 which attests to the fact that the instrument is internally consistent and satisfactory for the study. The researchers collected relevant responses through a mono-method (structured questionnaire) by mailing the questionnaire to the principals and SBMC members of the sampled schools, having written, convinced and solicited for their cooperation. Simple Arithmetic mean and standard deviation were used to analyse the data related to research questions through SPSS 23.0. However, for a decision regarding the mean rating, any questionnaire item with a mean rating $(\mathrm{X})$ is greater than or equal to 2.50 was accepted, and any questionnaire item with a mean rating $(\mathrm{X})$ that is less than 2.50 , was not accepted. This was based on the recommendation of Orji (2016) that 2.50 should be the benchmark for decision making when the research instrument is structured on 4 point scale.

\section{Results}

Research question 1: How has SBMC been getting involved in planning in public secondary schools in Abuja?

Table 1. Mean ratings and standard deviation scores of principals' on the extent of SBMC's involvement in the planning activities in public secondary schools in Abuja

\begin{tabular}{|c|c|c|c|}
\hline Questionnaire items & Mean (x) & SD & Decision \\
\hline 1. Involved in planning for school's financial resource & 2.24 & 1.18 & Not accepted \\
\hline 2. Involved in planning for school's physical or material resource & 2.53 & 0.12 & Accepted \\
\hline 3. Involved in planning for school's effective implementation of the curriculum & 2.45 & 1.71 & Not accepted \\
\hline 4. Involved in school's planning for staffing & 2.47 & 1.01 & Not accepted \\
\hline 5. Involved in school's planning on best practices for managing disciplinary issues & 2.65 & 1.21 & Accepted \\
\hline Cluster mean & 2.47 & 0.94 & Low extent \\
\hline
\end{tabular}


Table 1 above revealed that only 2 questionnaire items had their Mean ratings greater than 2.50 while the other 3 questionnaire items had their Mean ratings less than 2.50. Meanwhile, Table 1 which provides the result of the analysis for research question 1 on the extent of SBMC's involvement in the planning activities in public secondary schools in Abuja, has a mean rating of 2.47 which is less than 2.50. This is an indication that the extent of SBMC's involvement in public secondary schools' planning in Abuja is low. The pooled standard deviation of 0.94 also revealed that responses from principals and SBMC members of different schools are almost the same.

Research question 2: In what ways has SBMC been participating in the staffing of public secondary schools in Abuja?

Table 2. Mean ratings and standard deviation scores of principals' on the extent of SBMC's involvement in staffing activities in public secondary schools in Abuja

\begin{tabular}{|c|c|c|c|}
\hline Questionnaire items & Mean (x) & $\mathrm{SD}$ & Decision \\
\hline $\begin{array}{l}\text { 6. Participate in interviewing and selecting qualified teaching and } \\
\text { non-teaching staff for the school }\end{array}$ & 2.20 & 1.24 & Not accepted \\
\hline $\begin{array}{l}\text { 7. Participate in identifying training need and recommending appropriate training } \\
\text { for teaching and non-teaching staff of the school }\end{array}$ & 2.33 & 1.23 & Not accepted \\
\hline $\begin{array}{l}\text { 8. Participate in assessing and recommending teaching and non-teaching staff of } \\
\text { the school for due promotions and rewards }\end{array}$ & 2.39 & 1.12 & Not accepted \\
\hline $\begin{array}{l}\text { 9. Participate in disciplinary actions against erring teaching and non-teaching staff of } \\
\text { the school for improved school administration }\end{array}$ & 2.66 & 0.78 & Accepted \\
\hline $\begin{array}{l}\text { 10. Participate in sponsoring relevant training programmes for teaching } \\
\text { and non-teaching staff of the school }\end{array}$ & 2.54 & 0.89 & Accepted \\
\hline Cluster mean & 2.42 & 1.05 & Low extent \\
\hline
\end{tabular}

Table 2 above showed that only 2 questionnaire items had their Mean ratings greater than 2.50 while the other 3 questionnaire items had their Mean ratings less than 2.50. Meanwhile, Table 2 which addressed research question 2 on the extent to which SBMC has been participating in the staffing of public secondary schools in Abuja has a mean rating of 2.42 which is less than 2.50. This is a revelation that the extent of SBMC's involvement in public secondary schools' staffing activities in Abuja is low. The pooled standard deviation of 1.05 also revealed that responses from principals and members of SBMCs of different schools with regards to staffing activities in public secondary schools are virtually indifferent.

Research question 3: To what extent has SBMC been collaborating with public secondary schools in monitoring activities in Abuja?

Table 3. Mean ratings and standard deviation scores of principals' on the extent of SBMC's involvement in monitoring activities in public secondary schools in Abuja

\begin{tabular}{|c|c|c|c|}
\hline Questionnaire items & Mean (x) & $\mathrm{SD}$ & Decision \\
\hline $\begin{array}{l}\text { 11. Participate in monitoring school's recruitment and development programs } \\
\text { for teachers and non-teachers }\end{array}$ & 2.01 & 1.08 & Not accepted \\
\hline $\begin{array}{l}\text { 12. Participate in monitoring students' affair so as to ensure uninterrupted teaching } \\
\text { and learning activities in the school }\end{array}$ & 2.66 & 1.15 & Accepted \\
\hline $\begin{array}{l}\text { 13. Participate in monitoring and supervision of curricular } \\
\text { and extra-curricular programmes of the school }\end{array}$ & 2.57 & 1.11 & Accepted \\
\hline 14. Participate in supervising constructions and infrastructure maintenance in the school & 2.44 & 1.10 & Not accepted \\
\hline 15. Participate in monitoring school-community relationship for peaceful co-existence & 2.20 & 0.19 & Not accepted \\
\hline Cluster mean & 2.38 & 0.93 & Low extent \\
\hline
\end{tabular}


Table 3 above revealed that only 2 questionnaire items had their Mean ratings greater than 2.50 while the other 3 questionnaire items had their Mean ratings less than 2.50. Meanwhile, Table 3 which answered research question 3 on the extent to which SBMC has been collaborating with public secondary schools in monitoring activities in Abuja, has a mean rating of 2.38 which is less than 2.50. This implies that the extent of SBMC's involvement in public secondary schools' monitoring activities in Abuja is low and discouraging. The pooled standard deviation of 0.93 also revealed that responses from principals and members of SBMCs of different schools with regards to monitoring activities in public secondary schools are not so different, as shown by the convergence nature of the SD.

\section{Discussion}

Based on research question 1, on the extent of SBMC's involvement in the planning activities in public secondary schools in Abuja, it was found that school principals agreed that SBMCs to a high extent, get involved in school's planning for infrastructure need, development and maintenance, and disciplinary actions on staff members and students of the school. However, principals affirmed that SBMCs rarely get involved in school planning for financial resource need, mobilization and utilization; curriculum and extra-curricular implementation, and staff need, recruitment and development. This is in line with Hon and Alison (2014) which decried that the SBMCs are merely ceremonial and dysfunctional. In this situation, the activities assigned to SBMCs are not being discharged properly. It is understandable that both the earlier and the current study carried out by Hon and Alison (2014) adopted the same research design and method. The findings of both studies are positively related. This is based on the fact that both investigations were carried out in Nigeria, where the schools operate under the same ministry and education environment. In this educational environment, politics interferes with the finance and management of schools, in a manner that portrays prejudice and corruption.

Answers to research question 2 on the extent to which SBMC has been participating in the staffing of public secondary schools in Abuja showed that in terms of staffing, the SBMCs often participate in sponsoring relevant training programs as well as disciplinary actions against erring teaching and non-teaching staff of the school for improved school administration. However, SBMCs do not actively get involved in interviewing and selection, identifying training needs and recommendations of appropriate training, as well as assessing teaching and non-teaching staff of the school for due promotions and rewards. The findings are in tandem with Might (2015), which reported that the current state of stakeholders of SBMCs' involvement and participation in managing the school are not well-coordinated, hence do not play an active role. It is observed that Might's study was carried out in Ghana which often faces similar challenges in managing secondary education. No wonder, Grauwe (2018), pointed out that the inability to implement education programmes to the fullest has always been the major reason that the education systems in most African countries are still considered inferior to education standards in developed countries of the world.

Result for research question 3 on the extent to which SBMC has been collaborating with public secondary schools in monitoring activities in Abuja, found that SBMC's involvement in the monitoring of recruitment, infrastructure development and school-community relationship for peaceful co-existence is observed to be very low and insignificant. But, they are more active in monitoring and checkmating students' affairs and curricular and extra-curricular programs of the school. The finding is partly not consonant with the report by Saeid et al. (2012) that SBMCs have increased the involvement of parents, students, teachers, officials, principals and beneficiary groups of the community and local organizations in school management, thereby increasing the independence, responsibility and accountability of schools. Unfortunately, the previous study did not point out whether or not, the parents, students, and community members actually participate in monitoring teaching and learning in the schools. Saeid et al. (2012) did not pinpoint the exact management practices that SBMC members participate in. It is understandable that the current study highlighted that SBMC members' participation in recruitment, infrastructure development and community-school matters are not encouraging. 


\section{Conclusion}

From reports of findings of the study on the extent of school-based management committee involvement in public secondary schools administration in Abuja, Nigeria, it can be concluded that SBMCs have not truly been living up to expectations, in terms of collaborating with the schools to ensure efficiency and effectiveness in key areas of interest to this study. Based on revelations of the study in relation to the research questions, it is obvious that SBMCs have merely become ceremonial, and have not actively been partnering with the school in the area of planning, staffing, and monitoring of school programmes. Its involvements in planning, staffing, and monitoring were reported to be low through the arithmetic mean and standard deviation, and this is considered not to be encouraging, given the fact that the place of SBMC in partnering with the school cannot be over-emphasized. It is understandable that for schools to effectively meet the academic need of the Abuja community, their collaborations with the SBMCs have to be very active and productive. To this end, SBMCs need to become more committed to collaborating and helping the schools in terms of planning, staffing, and monitoring.

\section{Recommendations}

Based on the findings, the study puts forward the following recommendations:

1. The government through the Secondary School Board (SEB), Abuja should get more involved in supervising the activeness of SBMCs with regards to its involvement in the planning processes of schools in Abuja and beyond. By doing so, SBMCs' participation in planning with the school will improve.

2. The government through the Secondary School Board, Abuja should revisit and reevaluate the place of SBMCs recruitment and staffing of schools in Abuja and beyond. This would ensure that schools do not experience insufficiencies in the manpower needed in helping the schools actualize their set goals.

3. The government through the Secondary School Board, Abuja should get more involved in checkmating the activities of SBMCs in terms of their involvement in monitoring school activities in Abuja and beyond. Doing this, would improve compliance in the implementation of school programmes, thereby helping the schools achieve their goals for the Abuja community, and beyond.

\section{Acknowledgements}

The authors wish to appreciate each other for their selfless contributions to ensuring the success of this research. The wish to appreciate the journal outfit for providing a standard platform that ensured the outcome of the research was published and made accessible to the global community, and researchers for reference. The authors also wish to express their profound gratitude to Engr. Dr. Chris Emeka helped to fast-track the publication of the study.

\section{Authors contributions}

Orji, Friday Oko, Ph.D. Candidate, handled the objectives, research questions, methodology, data collection, analysis and presentation, discussion of findings of the study, and references.

Mando Patricia Nguwasen, Ph.D., handled the introductory part of the study.

Nzewi, Felicia Ebelechukwu, handled the conclusion and recommendation aspects.

\section{Conflicts of interest}

The authors declare no competing financial interest. 


\section{Funding source}

This study was funded through the personal savings of the authors.

\section{References}

Agustinus, B. (2009). The implementation of school-based management in Indonesia: Creating conflicts in regional levels. Journal of NTT Studies, 1(1), 16-27. https://zdocs.tips/doc/jurnal-bandur-2009-q182w5ozzg1v

Ahmed, A. A., \& Kazi, E. H. (2013). School-based management in Oman: Principals' views and understanding. International Journal of Academic Research in Progressive Education and Development, 2(3), 84-96. https://doi. org/10.6007/IJARPED/v2-i3/47

Ananda, W. P. (2007). General principles of management for educational planners and administrators. Reproduced from Basic Training Programme in Educational Planning and Management, August 2007 in consultation with UNESCO Regional Office for Education in Asia, Bangkok, Thailand.

Ayeni. A. J. (2010). Teachers' instructional task performance and principals' supervisory roles as correlates of quality assurance in secondary schools in Ondo State. Doctoral dissertation, Obafemi Awolowo University, Ile-Ife, Nigeria. http://www.sciepub.com/reference/155585

Ayeni, A. J. (2012). Improving school and community partnership for sustainable quality assurance in secondary schools in Nigeria. International Journal of Research Studies in Education, 1(2), 95-102. https://doi.org/10.5861/ijrse.2012. v1i2.49

Caldwell, B. J. (2005). School-based management. The International Institute for Educational Planning and the International Academy of Education, Paris and Brussels. http://www.iaoed.org/downloads/Edpol3.pdf

Cranston, N. C. (2001). Collaborative decision-making and school-based management: challenges, rhetoric and reality. Journal of Educational Enquiry, 2(2), 1-24. https://ojs.unisa.edu.au/index.php/EDEQ/article/view/555

Eziuzo, G. O., \& Enueme, C. P. (2013). Contributions of parents-teachers' association to secondary school management in Nigeria: Principals' perceptions. Journal of Emerging Trends in Educational Research and Policy Studies, 4(6), 835-841. https://docplayer.net/8891542-Contributions-of-parents-teachers-association-to-secondary-schoolmanagement-in-nigeria-principals-perceptions.html

Federal Ministry of Education (2006). Operation reach all secondary schools inspection exercise. Abuja: Federal Ministry of Education Publication.

Grauwe, A. (2018). Improving the quality of education through school-based management: Learning from international experiences. International Review of Education, 51(4), 269-287. https://eric.ed.gov/?id=EJ733515

Hanushek, Eric A., \& Woessmann, L. (2007). The role of education quality for economic growth. World Bank Policy Research Working Paper Number 4122, World Bank, Washington, DC. https://openknowledge.worldbank.org/ handle/10986/7154

Hon, K. Y., \& Alison, L. F. (2014). Principals and teachers' perceptions of school-based management. International Education Research, 2(1), 44-59. https://citeseerx.ist.psu.edu/viewdoc/download?doi=10.1.1.685.4616\&rep=rep1\&type=pdf

Might K. A. (2015). Involvement of school management committees in school-based management: experiences from two districts of Ghana. Educational Planning Journal, 24(3), 61-75. https://files.eric.ed.gov/fulltext/EJ1208100.pdf

Nwaka, G. N., Mordi, C., \& Nwafor, O. (2012). Examination malpractice in Nigeria (pp. 93-121). Onitsha: West and Solomon Publishing Coy. Ltd. https://www.worldcat.org/title/examination-malpractice-in-nigeria/oclc/862116952

Orji, F. O., \& Umoren, F. J. (2016). Role of educational administration in value re-orientation: Implication for sustainable national development. Journal of Reflective Thinking, 3(1), 92-103. https://www.researchgate.net/ publication/331148493_Role_of_Educational_Administration_in_Value_Re-orientation_Implication_for_ Sustainable_National_Development

Orji, F. O. (2016). Effectiveness of Instructional Materials in Teaching and Learning: Educational Implications. LAP Lambert Academic Publishing, Saarbrucken, Deutschland/GERMANY.

Orji, F. O., Eneasator, G. O., \& Nwaka, G. N. (2016). The place of information and communications technology in the administration of colleges of education in South-eastern, Nigeria: Implications for educational administration. Journal of Educational Studies and Research, 8(2), 10-25. https://www.researchgate.net/publication/331683654 The_Place_of_Information_and_Communications_Technology_in_the_Administration_of_Colleges_of_ Education_in_South-eastern_Nigeria_Implications_for_Educational_Administration_Introduction_and_Background $\mathrm{t}$ 
Saeid M., Sufean, B., \& Nader, B. (2012). School-based management, opportunity or threat. Procedia-Social and Behavioral Sciences, 69, 2143-2150. https://www.sciencedirect.com/science/article/pii/S1877042812056467

St. Otaf College (University), USA (2021, 6 June). Sample size. https://wp.stolaf.edu/ir-e/sample-size/ 